\title{
IPOSTAZE ALE EULUI CULTURAL ROMÂNESC ÎNTRE „BOIERIMEA MINTTII” ŞI „ROMÂNIILE” DIN ROMÂNIA
}

\begin{abstract}
Ivancu Emilia, Ipostaze ale Eului cultural românesc intre „,boierimea mintii" şi "Româniile" din România [Shapes of the Romanian Cultural Self between the Mastership of the Mind and the "Romanias" in Romania]. Studia Romanica Posnaniensia, Adam Mickiewicz University Press, Poznań, vol. XXXVI: 2009, pp. 179-192. ISBN 978-83-232-2035-0. ISSN 0137-2475.
\end{abstract}

The paper Shapes of the Romanian Cultural Self between the Mastership of the Mind and the "Romanias" in Romania aims at analysing the cultural Selves of three of the most important Romanian contemporary intellectuals - Gabriel Liiceanu. Andrei Pleșu, Horia-Roman Patapievici - as they are shaped in some of their memorialistic and essayistic works, and the possible relations and connections these Selves can have with the many "Romanias" existing today.

Într-un secol declarat de către filosofii lumii ca fiind unul din care a dispărut Alteritatea, drept pentru care este nevoie de reinventarea ei la nivel mental, într-o Europă care îşi redefineşte atât graniţele geografice, cât şi pe cele culturale, într-o Românie care nu mai este singulară sub raport politic, social şi cultural şi în care este la modã definirea cât mai multor Românii, şi în care toată lumea afirmă că ştie cum sunt aceste Românii, ni se deschid şi nişte uşi către o altă Românie, o Românie pe care puțini o acceptă, o Românie văzută de trei tipuri de euri, de trei personalități: Gabriel Liiceanu, Andrei Pleşu şi Horia-Roman Patapievici. O întrebare fireascã ar fi de ce tocmai ei dintre atâția alții. Răspunsul ar fi unul la fel de firesc: cei trei intelectuali şi scriitori români au fost în ultimii ani cele mai auzite voci ale culturii române, fiind în aceeaşi măsură criticați şi lăudați.

Cei doi „,boieri ai minții” (Şimonca, „Trăiesc atîta vreme cît mă indignez”. Interviu cu Gabriel Liiceanu", www.observatorcultural.ro), Pleşu şi Liiceanu, amândoi discipoli ai lui Noica din Şcoala de la Păltiniş şi cel de-al treilea, numit invenția Patapievici sau fenomenul Patapievici, au trasat traiectoria culturii române contemporane, lăsând în urmă atitudinea culturii de inferioritate şi înființând fiecare cel puțin o instituţie culturală de performantă: Editura Humanitas, care îi aparține lui Gabriel Liiceanu, poate cea mai elegantă editură românească la ora actuală, 
Colegiul Noua Europã, înființat de cắtre Andrei Pleşu şi care în fiecare an trimite numeroşi intelectuali români la studii in Europa şi revista de cultură Idei in dialog, al cărei director este Horia-Roman Patapievici şi care în numai trei ani de la înființare a reuşit să se impună ca o voce definitorie a vieții culturale româneşti. Aşadar, aceştia sunt protagoniştii acestui articol, al cărui scop este intrarea pe uşile mai mult sau mai puțin interzise oferite de ei, şi anume aparițile editoriale în special ale ultimilor ani, cu precădere scrierile memorialistice şi eseistice, care reuşesc atât de bine să contureze atât portretul autorului, cât şi pe cel al Romániilor în care fiecare s-a format şi în care ființează şi astăzi.

Textele pe care le vom aborda aici fac parte din categoria pe care Dan Cristea, în volumul Autorul şi Ficțiunile Eului, le aduce sub cupola „eului care se scrie", dar sub cupola acelui eu care „scrie şi se serie pe sine, scriind totodată lumea care îl înconjoarằ (Cristea, 2004: 5). Eul care se scrie este acel Eu din volumul de debut al lui Patapievici, Zbor in bătaia săgeții, din volumul care îndrãzneşte sã deschidã „uşa interzisă” a ființei lăuntrice şi care porneşte cẵtre Celălalt în căutare de Sine,

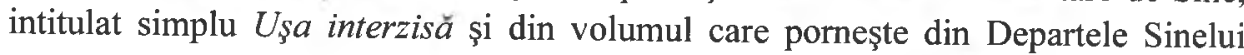
pentru a ajunge la Aproapele Celuilalt, sub forma scriiturii-plecăciune, intitulat sugestiv Declarație de iubire, ambele semnate Gabriel Liiceanu, ajungând la Eul care taie în carne vie, alunecând pe panta acelui „haz-de-necaz" specific culturii balcanice, dar care se deschide către lume precum împăratul din poveste $c u$ un ochi care râde şi cu un ochi care plânge din volumul Comédii la Porțile Orientului, semnat de Andrei Pleșu, și încheind cu Eul care problematizează, din volumul de conferințe semnat de Horia-Roman Patapievici, volum intitulat Discernământul modernizării.

Unul dintre scopurile nedeclarate ale jurnalului este lupta împotriva uitării, a neantului, a dezintegrării, a disoluției continuității fiintei, este o încercare de supraviețuire în fața trecerii şi pe-trecerii de fiecare zi, prin înregistrarea experiențelor ființei. Zbor în bătaia săgeții, cu subtitlul Eseu asupra formării este un anume soi de jurnal, în sensul că este o înregistrare a evoluției ființei celui ce se deschide spre lume, dar este, poate, mai mult decât atât, este, de fapt, o memorie a memoriilor, un Jurnal al Jurnalelor, o radiografie a zborului înscris pe pagini de jurnal, dar şi în camea ființei, care poartă, precum personajul lui Michael Ondatjee din romanul Pacientul englez, înscris pe propria-i piele, articulările, zvâcnirile, iubirile, suferințele şi, mai ales, bătaia aripilor dinspre Sine către lume, căci acest eseu cu iz de jurnal este un eseu despre Eul care se trăieşte pe Sine cu şi prin Ceilalți: „Nu ştiu cum şi-au păstrat alții integritatea în Comunism, dar eu m-am salvat prin prieteni." (Patapievici, 1995: 5); „Am scris această carte pentru cã eram pasionat de inteligență, cunoaştere şi viață, şi pentru că îmi iubeam prietenii. Fãră această iubire, câteva din cẫrțile mele, care $\mathrm{n}$-au fost scrise pentru a fi publicate, nu ar fi fost niciodată scrise" (Patapievici, 1995: 5).

Pe de altã parte, Gabriel Liiceanu atinge acelaşi subiect în Declarație de iubire: 
Fiecare om îşi alcătuieşte de-a lungul vieții un edificiu afectiv. Măsura în care el este e datã de consistenţa acestui edificiu, de mîna aceea de oameni - ei nu pot fi mulţi - pe care i-a preluat în el şi pe care i-a iubit fără rest, fărã umbră, şi împotriva cărora spiritul lui critic, chiar dacă a fost prezent, a rămas neputincios. Acești oameni puțini, care ne fac pe fiecare în parte sẵ nu regretắm că sîntem, reprezintă, chit cã o știm sau nu, stratul de protectie care ne ajută să trecem prin viaţă. Fiecare om face fată la ce i se întìmplă pentru cẫ este protejat în felul acesta. Fã̃ã acest zid de fiinte iubite care ne înconjoară (indiferent că ele sînt sau nu în viaţă), noi nu am fi buni de nimic. Ne-am destrăma precum într-o atmosferã în care frecarea este prea mare. Sau ne-am pierde, ne-am rẵtăci pur şi simplu în viață. Dacă ura celorlalți covîrșitoare uneori! -, invidia lor, mîrşăvia lor sînt neputincioase este pentru că existẫ cîțiva oameni pe care îi iubim pînă la capăt (Liiceanu, 2001: 3).

Declaraţie de iubire a lui Gabriel Liiceanu se leagă astfel, indestructibil, de Zbor în bătaia săgeţii, ambele cărți fiind memorie şi iubire, memorie a Sinelui şi iubire a Celorlalți, şi fiind, de fapt, jurnale nu în sensul obișnuit, ci jurnale ale afectelor trăite la nivel intelectual şi cultural, jurnale ale intelectului ce iubește aşa cum numai intelectul poate iubi, cu toată ființa.

Dacă spuneam mai devreme că Patapievici se folosește de scriitură pentru a înregistra jurnalul propriei memorii, pentru că naratorul se auto-decupeazã din propriile însemnări de Jurnal, iar dacă memoria este, dupã cum spune Derek Parfit, cea care ne face conştienți de propria noastră existență în timp (Parfit, 2002: 107), produsul finit este, astfel, ființa care se scrie pe sine din propria oglindire şi avem, în ultimă instanță, de-a face cu un joc de-a oglinzile, în care Eul se proiectează pe Sine în exterior către Ceilalţi, pentru a-şi răsfrânge ulterior imaginea înapoi către sursa-mamă, propria ființă, într-o nouă lumină asumată, a propriului destin trăit: „Nu există memorie în afara destinului, pentru că altminteri memoria se risipeşte în simple amintiri, în imagini disparate" (Patapievici, 1995: 47). Eul se descoperă, astfel, retrospectiv, de la primele amintiri, care se conturează timid în lumina copilului ce pozează la vårsta de şase ani într-un cititor precoce:

O poză de la şase ani mă arată citind concentrat o carte larg deschisã, de dimensiuni inquarto. Stau în picioare, cu fruntea plecatā, frizat cu exageratã netezime, animând un facies închipuit: eram un judecẵtor concentrat şi pedant. [...] Inutil sẫ precizez cẵ tânằrul în postură abstrusă era un histrion [...] la şase ani nu ştiam sã citesc dar afectam cu bunăvoințã impostura unei atitudini despre care bănuiam cã va deveni mai târziu familiară’. Micul impostor se arată însấ cu timpul a-şi fi mirosit destinul, căci autorul mărturiseşte un obicei cu valente ale vårstei pre-cititului, adulmecarea cărților, ca gest de apriorică înțelegere a propriului destin: „Iar mirosul care reprezintă cea mai veche amintire a mea este mirosul cernelii de tipar. Am și azi obiceiul de a mirosi cărțile. Este un mod de a regăsi vechea senzorialitate a tiparului, când încă înțelesul slovelor îmi era încercuit de stupoare. Prima formẵ a personalității mele este o impostură bine orientată. (Patapievici, 1995: 14)

Mai târziu, fiinţa coaptã se regăseşte de data aceasta autentic în universul cărţilor, asumându-şi destinul cu o conştiintă de invidiat, o conştiintẫ trează, atentă la propriile zvâcniri, o conştiință ce se auto-analizează permanent: 
Voi remarca faptul că formarea mea, potrivit limbajului curent, este legatẫ de cãrți, de experiențe şi de oameni. De fapt, este vorba de idei si de trupescul lor. [...] Cârțile care miau vorbit, mi-au vorbit pentru cẫ adresau în mine o parte care avea nevoie de ele pentru a se manifesta. Experientele pe care le-am trâit mi-au fost revelate pentru a declanşa in mine acele orizonturi care altminteri, dacã nu ar fi existat, nu mi-ar fi permis punerea în luminã a semnificaţiei care îmi orientează viał̧a. Fã̃pturile pe care le-am iubit au fost acelea care au iubit în mine ceea ce, fără iubirea lor, nu ar fi meritat sã supravieţuiască. Sunt de aceea recunoscător şi accept integral viața care mi-a fost datẫ (Patapievici, 1995: 119).

Din astfel de fragmente se decupează Eul narator, care îşi asumă atât zborul cât şi căderile, care conştientizează cu suferință că știe mai multe despre viaţa în formă virtuală a scriitorilor atât de iubiți precum Montaigne, decât despre viața propriului tată, a cărui dispariție va marca o altă criză, o altă ruptură şi a cărui despârțire de sânge doar sângele o cunoaşte. Eul se revendică atât din iubirile refuzate cât şi din cele oferite şi care asigură, până la urmă, constanţa de care are nevoie intelectul pentru a se cultiva, dar şi din prietenii menționați mai sus, volumul în sine luând forma confesiunii către unul dintre prietenii de suflet şi spirit ai autorului, Dan Waniek. Citatele din propriile Jurnale, Caiete de însemnări şi literatura de sertar (poezii, eseuri, proze) care se regăsesc şi ca bibliografie a volumului (singura, de altfel), pe lângă aerul de „redundanță publicistică" şi "ludic procedeu postmodernist" în care le vede învăluite criticul Vasile Spiridon în Fila de dicţionar (Spiridon, 2004: "Fila de dicționar" în Familia, http://revistafamilia.uv.ro/2004/9-2004/fila_de_ dictionar.htm.), considerăm că au, în ultimă instanță, tocmai rolul de oglindă a propriei memorii care se revendică din ea însăşi, care se dezvoltă din propria personalitate ce a traversat ani, atât în forma creativă de jurnal, dar şi în cea a memoriei active, ce se scrie pe ea însăși prin reevaluarea constantã a propriilor existențe.

Dacă Zbor în bătaia săgeţii este jurnalul-eseu-confesiune a Sinelui către lume, tot prin apelul la memorie, dar nu numai, se constituie şi Declaraţie de iubire a lui Gabriel Liiceanu. De fapt, întregul volum stă sub semnul iubirii care ia cele mai autentice şi estetice forme şi prin care Eul se pleacă cu graţie şi discreție în fața oamenilor care au dat măsura existenței sale. Cele mai frumoase pagini atât din punct de vedere estetic, cât şi autentic sunt cele dedicate Monicăi Lovinescu, văzută cu un fel de mysterium tremendum ca fiind ,O frumusețe matură, coaptă intelectual, care-mi produce o bucurie intensă, privind-o aşa, în efigie, ca pe marea mea iubire din altă viață" (Liiceanu, 2001: 8) şi lui Virgil Ierunca, ambii adoraţi într-o formă aproape filială şi, în acelaşi timp, care aminteşte de o anume venerație similară cu cea dedicată zeilor:

Aşa cum s-a întîmplat în cazul atîtor intelectuali romàni, Monica Lovinescu şi Virgil Ierunca au pắtruns în constelaţia mea umanã mai întîi ca o "voce". Deveniserã o funcţie, erau răzbunarea părții noastre care nu ajungea sẫ se rostească. Aceşti doi oameni au vorbit enorm, desfãşurîndu-se în timpul istoriei, recuperînd teritoriile pierdute ale cuvintelor. [...] Au vorbit din ce în ce mai mult, exact în mãsura în care în noi se articula, progresiv şi iremediabil, tăcerea. Dar nu ştiu dacă e corect sầ spunem „tăcerea". Pentru cã lumea asta 
a noastrẫ ajungea la ei sub formă de murmure, de şoapte, de rumori. Noi eram căzuţi în fundul gropii istoriei şi mai degrabă bolboroseam. Cu cît mai îndepărtate şi neclare erau semnalele trimise din această lume, cu atît trebuiau ei să le capteze şi să le desluşească mai atent. Cu cît mai aluziv şi în suferintă era limbajul nostru, cu atît mai răspicatã şi sculpturalâ trebuia sẫ fie vorbirea lor. [...] De cele mai multe ori întîlnirea cu omul întreg fie se soldeazã cu o dezamāgire şi atunci ne închidem în faţa lui, fie acceptarea şi respingerea coexistă şi atunci nu facem decît sẫ ne întredeschidem cẫtre el. Majoritatea relatiilor noastre sînt relații de întredeschidere. Ei bine, în cazul Monicãi Lovinescu şi al lui Virgil Ierunca, cunoscîndui, deschiderea s-a produs, s-a amplificat şi apoi s-a aşezat în propria ei certitudine (Liiceanu, 2001: 8).

Observăm, astfel, că şi în cazul lui Liiceanu, cartea se scrie din articulaţiile memoriei personale, pornind de la Sine cắtre Ceilalți, însă, după cum se va vedea, Liiceanu face apel şi la memoria colectivă, la memoria istoriei, la acel tip de memorie-instanță, al cărei rol este păstrarea candelei aprinse în permanență pentru ca nu cumva neantul să pună stăpânire peste oameni şi ființa lor. Capitolul dedicat Monicăi Lovinescu și lui Virgil Ierunca reuşeşte sắ îmbine perfect cele două tipuri de memorie.

Eul autorului, asumându-şi şi rolul celui care veghează dacă lumina încă arde, memoria-instantă la care face apel înlesnind o pluralitate a vocilor care devin una, comentează momentul în care, din ordinul lui Nicolae Ceauşescu, redat stilizat de o ziaristă franceză în 1985 care il cita pe Pacepa, Monica Lovinescu urma să fie mutilată:

Să i se închidă gura. Nu trebuie ucisã. $\mathrm{N}$-avem nevoie de anchete americane şi franceze care ne-ar pune în situaţii dificile. S-o facem zob. Să-i spargem dinţii, falca, să-i rupem brațele. Să nu mai poatã niciodată vorbi sau scrie. Sã devinã un exemplu de neuitat pentru ceilalți. Sã̃ fie bắtută la ea acasã pentru ca să învețe şi ea şi alții că nu există nici un adăpost sigur pentru calomniatorii dictaturii proletariatului. Nici chiar în propria lor casă (Liiceanu, 2001: 13).

Atacul de mutilare asupra Monicăi Lovinescu „s-a soldat numai cu o zi de comă, cu un traumatism cranian, cu o fractură la baza nasului şi cu un hematom de la umãr pînẫ la mînã" (Liiceanu, 2001: 13), datoritã faptului că s-a întâmplat să treacă un vecin prin zonă.

Acelaşi ton îl menține Eul rememorator şi în capitolul intitulat Jurnal de pe marginea unei gropi comune, care se evocă prin intermediul lansẫrii unui volum intitulat Lexiconul negru. Unelte ale represiunii comuniste, scris de Doina Jela, chiar într-un loc unde erau îngropați duşmanii poporului:

La 3 km de Valea Neagră - la Peninsula - s-a aflat între 1950 şi 1953 unul dintre cele 14 lagăre de muncã de la Canalul Dunăre-Marea Neagrã, inaugurat, acesta, de Gheorghiu-Dej în 1950 (pare-se că la sugestia lui Stalin), pentru a-i "ocupa" pe intelectualii, tăranii şi muncitorii care nu înțeleseserẫ, în toiul luptei de clasã, de ce parte a baricadei trebuie sẫ se aşeze (Liiceanu, 2001: 45). 
Tonul abordat este unul golit de putinţă, iar când citeşti, ai senzația că ai un aparat de filmat în brațe şi că vizualizezi totul mecanic, căci Eul simte atât ruşinea istoriei pe care au făcut-o cei dinaintea lui, cât şi neputința prezentului. Autorul îşi/ne adresează firesc întrebarea: cum se poate citi o asemenea carte, a torţionarilor, care rămân în ultimă instanță cunoscuți doar victimelor, căci istoria nu păstrează imaginile ororii din acest caz? Şi tot singur, neputincios, Eul răspunde, ca pentru Sine, dar lăsând în urmă un ecou de netăgăduit, însă care iți sună în urechi nu dulce, ci surd şi greu:

lată, deci, o posibilă lectură: personajele se impun după o epicã şi o stilistică a torturii, dupã natura isprẵvii care, în imaginarul detentiei, îi făcea inconfundabili. Tiberiu Lazấr, comandantul închisorii de la Peninsula, zdrobea faţa şi dinții deţinutului cu o piatră (,Într-una din veri a năvẫlit în baraca noastră un om cu capul roşu de sînge, care nu mai putea să vorbeascã, ci răgea ca un animal şi căuta să se ascundā. Nu bănuiam ce se putuse întîmpla cu el, parcă intrase cu capul în gura unui tigru". Nenorocitul se numea Maxim şi ajunsese la raportul comandantului Lazăr Tiberiu care a luat o piatră şi l-a lovit peste faţă pînă i-a scos dintiii”. - Lexiconul, p. 158). [...] Liviu Borcea, comandantul penitenciarului de la Capul Midia, verifica starea cadavrelor înfigînd în ele o țeapă lungã de fier (Lexiconul, p. 52). Emil Brînzaru, colonel de Securitate, şeful echipei de bătāuşi profesionişti din Direcţia de Cercetãri Penale a Securitătii, avea ca specialitate zdrobirea penisului condamnatului şi bătaia la tắlpi pînă cînd obţinea efectul scontat: "picioare de elefant" (, ,... adus la 7-8 zile la o nouă anchetă, omul mergea de-a buşilea, în genunchi şi în mîini. - Lexiconul, p. 55) (Liiceanu, 2001: 45).

Declaratie de iubire este o carte a portretelor, a ipostazelor pe care le ia Iubirea, dar nu numai iubirea personală a Eului, ci Iubirea Omului către Celălalt, Iubirea-Închinare, precum capitolul de mai sus, Iubirea intelectului, ce se metamorfozează în capitolul analizei mai puțin convenţionale a piesei lui Shakespeare, Romeo şi Julieta, este Iubirea omului de cultură care creează medalioane precum capitolele dedicate lui Horia Bernea, Henry Wald, Mihail Sebastian. Însă, între aceste portrete construite din memoria personală, la care se adaugã memoria culturală, sunt câteva care revin şi în următorul jurnal, Uşa interzisă, ele fiind, de fapt, personalitắtile care au marcat evoluția spirituală şi culturală a autorului şi la care Eul simte nevoia sã revină neîncetat, pentru simplul fapt că ele reprezintă propria lui lume. Între aceste portrete se află Constantin Noica, mentorul lui Gabriel Liceanu, Andrei Pleşu, prietenul de o viață, Emil Cioran şi evident „Ieruncii”, aşa cum îi alintă autorul în repetate rânduri.

În capitolul intitulat Moartea lui Cioran, Eul narator reuşeşte sã creeze un eseu despre esența cioraniană, aici memoria personalã amintind personalitatea unui om care avea nostalgia, ,regretul de a nu putea traversa regnurile în sens invers, pentru a reintegra fericirea animalului, a plantei şi a pietrei" (Liiceanu, 2001: 24) şi care ajunge să-şi împlinească destinul în brațele propriei dorințe, bolnav de Alzheimer, ființa cioraniană retrăgându-se încet, aşa cum şi-a dorit, în ființa Marelui Anonim, pentru a folosi expresia blagiană. Medalionul Emil Cioran este unul care frizează 
istoria literară, ca de altfel şi cele dedicate Ieruncilor, lui Mihail Sebastian sau lui Noica, volumul în sine fiind susținut, în cazul portretele celor menționați, cu fotografii inedite, care sunt o mârturie în plus a Iubirii cât se poate de palpabile a Eului.

Andrei Pleşu, la care ne vom referi puțin mai târziu, beneficiază de un portret din care răzbat candoarea şi apropierea, fiind unul dintre acele ființe-pereche de care sufletul autorului se simte legat atât prin istoria/istoriile trăite împreună, cât şi prin afinitatea valorilor:

Personaj vast, cu resurse multiple, dotat cu o aroganță de catifea şi surclasînd cu amabilitate pe oricine, obținând cu uşurintã performanța și strălucirea în tot ce i se întîmplã sã facã, modulînd în orice registru uman (devastator în deriziune şi adorabil la ceasul şuetei), apt să ia forma oricắrui context (de la petrecere cu lăutari la întîlniri cu domni în vîrstã si regine), incapabil visceral să tolereze afrontul, pătimaş şi nedispus să-şi recunoască greșeala, dotat cu o bunẫ-credințã care uneori se învecineazã cu prostia, devenind relativist şi îngăduitor cînd e confruntat cu judecătile tranşante, dar grav şi slujind patetic adevărul cînd sînt lezate principii, distant şi angajat, atras de rigori monahale şi topindu-se cu voluptate în vanitățile lumii, Andrei Pleşu excită lesne fantasma colectivã a intelectualului român care, de la revoluţie încoace, pẳaãlit în cîteva rînduri de istorie şi devenit mefient, a decis să aleagã vigilența şi să practice subtilitatea ca metodă şi atunci cînd nu e cazul (Liiceanu, 2001: 30).

Vechiul prieten va reveni în mod constant în $U$ şa interzisă, animând aceleaşi sentimente şi întărind aceeaşi atitudine de complicitate a prieteniei, cum singur sugerează Liiceanu, în comentariul la o fotografie din volum.

Dacă în Declaratie de iubire, Eul care (se) declară este unul a cărui traiectorie rămâne una în afara lumii, este deschis către lume pentru că scopul lui este de a se mărturisi, capitolele distincte ale cărții, având uneori valoare de confesiune cắtre personajele sale, tonul - unul direct, dar netemător, afirmând voința Eului de a se


un jurnal este de obicei un soi de literatură de sertar, o formă prin care Eul se ascunde de lume, se închide şi se deschide doar în şi cắtre sine însuşi, pe când $U_{\text {şa }}$ interzisă este un jurnal programat, este scris pentru a fi făcut public şi pentru publicare, este citit deseori în fała prietenilor care îl analizează. Gestul de scriere devine, astfel, al unui Eu ce se doreşte a se deschide atât către Sine dar şi că̌tre Ceilalți, oferind o lume integratoare unei lumi integrante. Este un Eu bolnav, după cum mărturiseşte însuşi autorul, care încearcă să se vindece prin simplul, dar, totuşi, complicatul proces al scrierii-confesiune. Eul, scriindu-se, se re-descoperă pe Sine printre Ceilalți, renãscând din propria ardere a ființei pentru a-şi recupera iluziile pierdute: „Ce mai e şi cartea asta? Jurnal, de fapt, nu e eseu nu e, tratat nu e, roman nu e. Cel mai corect ar fi să spun că este explozia (neîncadrabilă) a ființei mele pe parcursul unui an. Dar ce lucru formidabil: această explozie mă redă mie însumi întreg" (Liiceanu, 2003: 3). Întregul text arată semnele unei lupte a Sinelui cu propriul Eu, şi, până la urmă, gestul de scriere şi confesiune a Eului cắtre lume, ce se poate explica tocmai prin aruncarea cu capul înainte - în aparență căderea în 
nefericita stare a auto-compătimirii şi a patetismului cras, conştientizarea propriei stări şi mai ales a faptului că Eul este bolnav, din lipsă de iluzii - conferă întregii cắrți o sinceritate debordantă, şi sforțarea nu mai este sforțare, ci existenţă naturală, prelungită în cugetare:

Medicii numesc această stare depresie. Eu o înteleg mai bine ca dezagregare a sistemului de iluzii în virtutea căruia înaintăm, fãptuim, ne agităm, dăm contur clipei următoare şi zilei de mîne. "Sistemul de iluzii" - acesta este pintenul întregii noastre vieţi, „morcovul existențial" pe care viała ni-1 aşazã şi ni-1 flutură sub nas, planurile pe care le alcătuim din propria noastră substantă vitală și pe care le ridicăm, ca pe un prunc nou-nắscut, deasupra capului nostru, pentru a le aşeza apoi, de îndatẫ ce le-am făcut, la o distantấ convenabilẫ de locul în care ne aflấm, urmărindu-le neabẫut prin ani, asemeni unui animal care merge, halucinat, pe urma de miros a hranei sale. Aşa se naşte sensul vieții noastre. Numai cã hrana pe care o adulmecăm fã̃ã încetare cu fiecare zi nou începută, noi sîntem cei care o secretấm şi tocmai fabricarea aceasta neîntreruptã a ,sistemului de iluzii” este garanţia sănãtẫţii noastre mentale (Liiceanu, 2003: 3).

Ceea ce exprimã autorul în citatul redat este, până la urmã, un fapt de viață, iar când se scrie pe Sine, Eul vorbeşte nu Cititorului, ci altor Euri care se reflectă pe ele însele în oglinda Eului confesor. Scrierea, convalescența, vindecarea se desfăşoarã pe parcursul unui an şi jumătate, în care, printr-un proces de-a dreptul dionisiac, Eul se purifică prin descărcarea tuturor afectelor, prin asumarea tuturor regretelor, prin acceptarea propriului Sine, uman în toate colțurile fiinţei. Traiectoria este una dinspre htonic spre apolinic, dinspre zonele întunecate ale ființei cắtre azurul eliberator al adevărului ființei, care mai poate re-naşte doar prin scuturarea întregului praf din camera interzisá.

Uşa interzisă pe care o deschide, însã, Liiceanu se scrie şi ea tot prin apelul la memorie. Sinele se retrăieşte prin rememorarea propriei vieți, o rememorare activă, susținută de reflecția prezentului. O dată, uşa se deschide către fiul lui, Ştefan Liiceanu, cartea devenind gestul cererii iertării către fiul care nu şi-a avut tatăl aproape niciodatã lângă sine, gest care pare patetic, dar care acoperă una dintre cele mai frumoase părți ale cărții:

Fiul meu şi-a fắcut viața singur. Mai ales şi-a fấcut-o. Putea să eşueze înãuntrul unei relatii între părinti distruse, să devină autist, să urască viał̦a, să se urîtească. sã nu devinã nimic. Putea să se înstrăineze de toţi şi sã-şi piardă capacitatea de a iubi. Pentru cã de fapt a crescut singur, ca un vlăstar în pãdure, navigînd în atmosfera capricioasă dintre mama şi tatāl lui, duplicitar de mic, încercînd sẫ caute soluţii de zi cu zi pentru frustrẫile, geloziile şi revendicările fiecăruia dintre ei. El e cel care a trebuit sã se poarte matur, prins la mijloc între infantilismul celor doi. Mi-a lãsat drept moştenire un enorm capital de culpã pentru că prin despärţirea părinţilor, care s-a petrecut înainte de naşterea lui, a fost de la bun început privat de atmosfera familiei, de putinţa de a gîndi simultan şi de a cuprinde sub aceeaşi privire personajele care în viata unui om poartã numele unic de „mamă" şi „tată". „În această privinţâ,, mi-a mãrturisit într-o zi, cînd avea 16-17 ani, ,sînt ca orbii din naştere cărora nu le poti explica ce sînt culorile" (Liiceanu, 2003: 46). 
Tatâl se mărturiseşte, astfel, către fiu, într-o declarație de iubire şi Eul se simte mai eliberat.

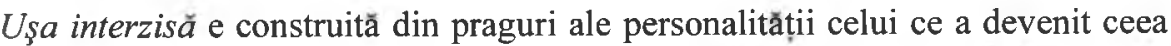
ce este astăzi, este o rememorare a evoluției ființei. Căci Ființa este, până la urmă, subiectul acestui jurnal, Ființa care îşi resimte originea filosofică (să nu uităm ca Liiceanu este absolvent al Facultății de filosofie şi discipolul lui Noica), iar filosofia pe care nu o resimte ca profesie, ci ca ontologie, este cea care salvează cartea de la eventuala cădere în patetism. Autorul mărturisește experiența ideii filosofice astfel:

După ce am scris 200 de pagini despre limită mi s-a părut că am aflat „ce este viața”. Ba mai rẩu: l-am descoperit pe Dumnezeu la capătul unei demonstrații, ca ,sursă a libertāţii noastre". Mă chinuisem, ce-i drept, să înteleg, dar lucrul dăduse roade: dintr-un pas ajunsesem la capẫul drumului. Nu mă aflam, cum cereau unii filosofi, pe drum, ci la capătul lui. Cu o simplă idee, ca o săgeatã bine orientată, atinsesem tinta. S-ar părea că ideea mea era atît de bunã̃ încît, pusẫ cît de putin la lucru, îşi epuizase domeniul şi mijloacele lui. La capãtul cấrtii mele filosofia se topise şi dispăruse ca prin farmec (Liiceanu, 2003: 11).

Filosofia, totuşi, nu-l va părăsi niciodată, discursul mustind a Noica şi a Heidegger, a Suflețel şi a Ființă, însă din bătălia inevitabilã care s-a creat, până la urmă, între filosof şi scriitor în acest jurnal, cu siguranță învingător a ieşit scriitorul, care mărturisea la un moment dat, întrebat fiind ce apelativ preferă: scriitor, filosof sau editor: „Scriitor. Adevărul este că asta am făcut cu precădere in viață: am scris cîteva cărți. Şi asta îmi place cel mai mult. «Filosof» însă nu merge. Filosofi sînt vreo 10-12 pe lume, eu doar mă îndeletnicesc cu filosofia" (Şimonca, www.observatorcultural.ro).

Unul dintre cele mai interesante aspecte ale jurnalului este faptul că în el se regăsesc numeroase trimiteri, cât mai diverse şi diversificate, la filosofie, muzică, literatură, viața personală, istorie, artă culinară. Un lucru nou pe care 1-a adus Liiceanu în România, odată cu publicarea jurnalului său este un alt jurnal, care ține de culisele istoriei literare, jurnal ce s-a încetắtenit în critica românească de azi sub titlul Jurnalul caprei metafizice. Acest jurnal al „caprei metafizice” este jurnalul lui Friedgard Thoma, ultima şi răscolitoarea iubire a lui Emil Cioran, jurnalul fiind descoperit din întâmplare pe internet de unul dintre tinerii cu care Liiceanu se afla la Heidelberg în anul 2003: „Cătălin, amușinînd astẫzi pe internet, a căzut peste o carte neaşteptată: Friedgard Thoma, Um nichts in der Welt. Eine Liebe von Cioran, Weidle Verlag, Bonn, 2001" (Liiceanu, 2003: 57). Povestea celor doi a pornit de la faptul că tânăra profesoară de filosofie se îndrăgosteşte în 1981 de aforismele septuagenarului Cioran, îi scrie, cei doi se întâlnesc (în absența lui Simone Boue, prietena lui Cioran) şi iată ce se întâmplă:

Totul începe, aşadar, de la operã. Relaţia dintre cei doi se angajează mai întîi prin vorbe şi în spirit, şi între ei strẫjuieşte mereu, ca supremã justificare a întîlnirii lor, admirația declarată a Friedgardei pentru aforismele lui Cioran. Mai există însă un mic amănunt şi acela este fotografia pe care Friedgard o alắtură scrisorii sale din 12 aprilie. [...] „Manipularea fizicâ”, 
pe care Friedgard i-o va reproşa mai tîrziu lui Cioran, este inaugurată şi perpetuatã de Friedgard însãşi: la fiecare întîlnire existā o laturã a seducției fizice foarte bine pusă la punct, iar eroina are grijã să ne vorbească mereu despre frumusețea ei, despre felul în care îşi compune aparitiile, despre admiraţia pe care o stîmeşte în jur. Nici o mirare că Cioran va răspunde acestui scenariu al seducției şi va deveni din prima clipã victima lui. Cấci din prima clipă, sub noianul de vorbe în care cei doi se îngroapă, Cioran descoperấ în el o irepresibilā atractie fizică (sinnlich, „senzorial” e cuvîntul care revine mereu), iar scrisoarea care urmeazã după prima întrevedere la Paris este plinã de fantasme erotice şi stẫ sub semnul senzualului şi al corpului: „Ați fost oarecum îngrozită cînd v-am vorbit de o înclinatie «perversă)» pentru corpul dumneavoastră. Pervers nu era cuvîntul potrivit; scharf, «extrem de clar», am vrut sẫ spun. Intensitatea stării mele cerea o expresie ne-naturalâ" (19 aprilie 1981). Cert este cã din clipa aceasta Cioran îşi trâieşte iubirea pasional, iar intensitatea ei o resimte mai întîi negativ, în planul frustrării sexuale şi al unei sfişsietoare gelozii. Tot ce se întîmplã între prima întîlnire (în aprilie, la Paris) şi cea de a doua (în mai, cînd Cioran petrece două zile cu Friedgard în apartamentul ei din Köln) nu reprezintă decît precipitarea disperatã din partea lui Cioran a deznodāmîntului sexual. Care este un fiasco. [...] Ce blestem pentru Cioran să se pomenească, în plinã detentă eroticã, castrat cu armele înseși ale filosofiei! (Liiceanu, 2003: 57).

Povestea acestei iubiri a lui Cioran revine mereu asupra Eului care se scrie, o poveste între un filosof şi o capră metafizicã care, în timp ce şi-a dorit de la Cioran aforisme, îi face acestuia un portret asemănător unei păpuşi mecanice:

Îmi cade de-abia acum în mînă interviul din România literarã (12 dec. 2001) cu Friedgard Thoma. „A existat un contrast puternic între faţa umană şi cea «auctorialẫ a lui Emil Cjoran?” este întrebatã eroina noastră. Răspunsul este stupefiant: „,Da, şi încerc chiar la începutul cărții mele să descriu acest contrast. Cioran evolua mult prea vădit în registrul anecdotic al conversaţiei noastre [...] şi nu părea prea interesat să mi se adreseze în termenii în care eu îl cunoşteam din lectura aforismelor şi în care doream să-l aud! Trebuia mereu sã1 readuc la acel nivel..." Bietul Cioran! Ce neşansã pe el sẫ încapã pe mîna unei asemenea capre metafizice! Friedgard vine la întîlnirea cu Cioran programată să cunoască nu un om, ci un fabricant de aforisme, în vreme ce Cioran vede în ea ceea ce Friedgard şi era înainte de a se fi automutilat cultural: o tînãrã femeie frumoasã. Fiecare cunoaşte propria lui dezamăgire: Friedgard descoperă un personaj şarmant care îi vorbeşte despre chiriile din Paris, iar Cioran va descoperi în pat capra metafizicã (Liiceanu, 2003: 196).

Acest Eu care îşi reglează conturile cu lumea din jur şi cu propria existență, recurge şi la memoria istoriei în repetate rânduri, când prezintă situaţii tragi-comice din perioada comunistă sau când face portretul Regelui Mihai, evocare ce frizează uşor pateticul când mărturiseşte că Regele ,are, cred, cel mai frumos plîns din plînsurile pe care le-am văzut" (Liiceanu, 2003: 128). Apar evocate momentele studenției, prietenii Andrei Pleşu, Monica Lovinescu şi Virgil Ierunca, seri cu muzică şi discuții intelectuale alắturi de oameni iubiţi, trãiri, întrebări, cugetãri, momente de restrişte şi disperare, toate cele ce se pot regăsi în viaţa unui Eu uman, care se trăieşte pe Sine între filosofie şi celelalte arte. 
Uşa interzisă este, până la urmă, o poartă de trecere către mai multe tărâmuri, atât pentru cel care scrie, cât şi pentru cel care citeşte. Pe de altă parte, este o completare la Declaraţie de iubire şi Jurnalul de la Pãltiniş̧, o altã fereastră spre aceeaşi lume a autorului, de data aceasta privirea nemaifiind mijlocită de geamuri sau perdele, Eul descoperindu-se fără ascunzişuri, luându-şi prin surprindere cititorul, care se vede dintr-o dată plonjând într-o lume colorată, în care nu lipseşte nimic din farmecul vieții, dar în care Eul alienat al autorului nu mai are acces direct datorită prăbuşirii sistemului de iluzii, datorită prafului şi lucrurilor nearanjate din cắmara Fiinţei.

Interesant este felul în care această cameră interzisă este asemănată de criticul literar Vitalie Ciobanu cu camera interzisă din basmele românești:

În basmele româneşti, cu inepuizabila lor încărcătură sapientială, existã o situatie tip în care eroului, un Fắt-Frumos ajuns, după îndelungi peregrinări pe meleaguri străine, în ospetie la o gazdā mārinimoasă, aceasta îi înmânează cheile de la odăile fabulosului său palat, invitându-l sẫ se bucure de toate darurile posibile, cu exceptia unei singure camere, unde are accesul oprit. Avertismentul sunã aspru: îtị vei regreta amarnic ispita neostoită. Însã dupã ce va profita din plin de ospitalitatea castelanului, tocmai uşa interzisã va fi cea care va aprinde neliniştea şi dorinţele eroului nostru. Prețul încălcării consemnului va fi teribil: dincolo de pragul vegheat cu atâta strẫşnicie, el va trắi experiența cunoaşterii şi remuşcarea.

(Ciobanu, 2002: „Jurnalul unui filosof 'apostat". Contrafort, 12/98, Decembrie, http: //www.contrafort.md/2002/98/448.html.)

Acel teritoriu unde nu se poate intra pentru cã e periculos se regăseşte la finalul vindecării şi vine ca o cortină ce cade peste un spectacol încheiat, anunțându-şi, de fapt, nu sfârşitul, ci tocmai perenitatea, permanența din fiecare dintre noi. Imaginea finală este a unui surâs înțelegător adresat fiecărui Eu în parte:

Joi, 26 septembrie. Dincolo de „uşa interzisă” clocoteşte viaţa morală a fiecăruia dintre noi. În odaia aceasta, în care nimeni nu poate pằtrunde fără voia noastră şi a cărei uşă rắmîne pentru ceilalţi cel mai adesea închisă, se desfâşoară drama fiecărei vieți. Acolo au loc complezențele noastre cu noi, acolo își au sẩlaşul duplicitătịle noastre, de acolo ne procurăm scuzele pentru tot ceea ce facem. Însă tot acolo apare şi creşte dezgustul de noi, acolo cad mâștile pe care îndeobşte le purtầm, acolo are loc suplicierea noastră, judecata noastrã şi, în sfirşit, tot de acolo obținem un nou termen de grație pentru a putea parcurge o altă bucată din drumul pe care-l mai avem în față (Liiceanu, 2003: 198).

Dacă până în acest moment Eurile care ni s-au perindat prin fața ochilor au fost fie Eul care se deschide către Sine pentru se regăsi, fie Eul care se deschide către ceilalți pentru a se mărturisi, fie Eul ce se împarte între lumile Ființei, trăind prezentul, trecutul şi viitorul când ca timp integrator al Ființei, când ca sacadare a lumii gazdă, în Comédii la Portile Orientului de Andrei Pleşu, vom descoperi un Eu ce se desfãşoară în mijlocul larmei, în mijlocul Lumii, este Eul ce devine pulsul propriei proximități, pe care o stăpânește cu instrumentele snoavei, ale inteligenței ce muşcă în timp ce zâmbeşte, este Eul care cu un ochi râde şi cu unul zâmbeşte, este Eul matur ce experimentează lumea şi toate ale ei, bune şi rele. 
Volumul este alcătuit din eseuri publiciste, grupate în cinci capitole, fiecare abordând o anumită tematică: Ce țară-i asta?, Toxine mari şi mici, Cartelul patriotilor, Înăuntrul trebilor de-afară, În lume nu-s mai multe Românii. Singurul cusur al volumului este faptul că aproape jumătate din el a apărut în volumul Obscenitatea publică, şi, într-un fel, cititorul fidel al lui Andrei Pleşu se simte oarecum trădat.

Astfel, tema centrală a Comédiilor este România de azi, a prezentului, în care Descriptio Moldaviae a lui Dimitrie Cantemir este reiterată când se descrie viața mioritică a Moldovei prezentului, autorul povestind câteva zile petrecute cu nişte prieteni din America, ce vedeau România, aproape ca toţi turiştii străini, ca un fel de „Celălalt tărâm”, „Capătul lumii!”. Străinii plimbați de Pleşu îmbină curiozitatea nerăbdătoare de a-l întâlni pe Dracula, frica de copiii străzii, SIDA, cu mirarea de a vedea pe străzi oameni normali, ba chiar mărcile teritoriilor normale, Coca-Cola şi Mercedes-ul. Punctul culminant ale experienței intelectualului român ce-şi însoțea prietenii veniți din Trara corectitudinii politice este momentul în care vizitează o mânăstire din Bucovina: primul moment delicat apare în momentul în care vor sã intre în mânăstire şi măicuța însoțitoare cere irevocabil aparatul de fotografiat, în ciuda faptului că străinii noştri mărturisesc cắ nu mai există film în aparat. Străinii se simt jigniți şi cer recipisă, iar maica ultragiată răspunde: „Asta e culmea! [...] Aşa ceva n-am mai auzit!" (Pleşu, 2005: 56). Străinii devin şî mai impacientaţi când li se explică programul iconografic al peretelui de vest al bisericii:

[...] fluviul iadului şi, de-o parte şi de alta a lui, mântuiții şi damnaţii. Cine sunt damnaţii? Turcii. E normal. Erau duşmanul cotidian al creştinilor. Şi mai cine? Jidanii. Care l-au omorât pe Cristos. Şi mai cine? Negrii. De ce? În armata turcă erau şi mercenari negri. Şi mai cine? Armenii. Armenii? Da, armenii. Erau eretici, de credintấ coptă. Pas de tradu toate astea într-o engleză politically correct...Tocmai îi asigurasem pe prietenii mei că xenofobia n-are prizã realã în popor (Pleşu, 2005: 56).

La o altã mânăstire, autorul se vede în fața unei alte replici intraductibile pentru oaspeții noştri: „Au ei, acolo, la ei în America mănăstiri ca ale noastre? Când s-a făcut mănăstirea ei nici nu existau! [...] Ce ne-a venit de la ei? Sectele!” (Pleşu, 2005: 56).

Eul nostru ne duce, după incursiunea în Moldova lui Dimitrie Cantemir, în lumea speciilor de imbecili, care, ne spune autorul, nu disting ,între est-europeni, vest-europeni şi americani” (Pleşu, 2005: 56), ne spune cum stấ treaba cu tutuiala împrumutată de la americani, în care este la modă să-i spui Bill lui Clinton, Vaclav lui Havel sau tutuiala ieftină de genul: „Drăguță..., Măi dragă... sau simplu Boule!” (Pleşu, 2005: 56). Aflăm şi despre un gen literar aparte practicat în perioada comunistă - dedicația - de subînțeles că „Fiului cel mai iubit al țării”. Unul dintre capitolele cele mai savuroase ale cărtii îl reprezintă cel în care Andrei Pleşu vorbeşte în acelaşi mod ironic, zeflemitor despre experiența lui ca ministru, o dată ministru al culturii şi apoi ministru de externe, care primea scrisori similare celei de mai jos: 
Subsemnatu U.I. [...] declar următoarele probleme care mi s-au întâmplat în Istambul (Turcia) am fost bẫtut, înjunghiat de cuțit, în care concubina şi-a bătut joc de mine am fost dezbrẫcat de haine, am luat-o cu scopul de a câştiga o pảine, dar ea mi-a fắcut greutăți. Am venit din Turcia, i-am spus sectoristului nici nu m-a băgat în seamă în care el se folosea de ea la altã persoană acasă pe nume A.M. [...] Vă rog foarte frumos dacă se poate sẵ se facã ordine şi disciplinã când la noi Poliția s-au umflat în ei şampania şi vinufructu de Panciu (Pleşu, 2005: 56).

Descoperim, astfel, în paginile volumului că ne-am trezit în mijlocul Balcanismului, într-o lume pestriță care ne arată ca Mitică nu a murit, ba chiar mai are mult de trăit, descoperim un Mitică guraliv care semnează petiții şi le dă anonime, ba îi chiar place Eminescu şi vrea cu tot dinadinsul să-l recite „cu ton neurastenic” sau, mai rẫu, „cu glas viril” şi „virtuozitate pulmonară”, sau în variantă când „sfătoasă, academică”, când „maniaco-depresivă, intensă, de o anxietate pârjolitoare”, însă din păcate, „Ceea ce au în comun toate speciile de recitatori invocate este, în ciuda aparențelor, indiferența fată de Eminescu." pentru majoritatea Eminescu fiind de fapt, „un pretext gras al exhibării de sine” (Pleşu, 2005: 49-50).

Acesta este Eul din Comédiile lui Pleşu, direct, dureros de direct şi dureros de sincer, un Eu care îşi iubeşte țara nu numai pentru că au existat Ştefan cel Mare sau Mihai Viteazul, Eminescu şi Călinescu, ci şi pentru că România nu este perfectă, şi de asemenea pentru ,capacitatea de a petrece, răbdător, intre imperii, combinând multicultural, arhaicul cu postmodernitatea, în aşteptarea - străveche - a alinierii nord-atlantice..." (Pleşu, 2005: 196).

Pentru a încheia rotund, ultima referire va fi la o carte în care Eul se adresează direct tuturor, o carte intitulată Discernământul modernizării, semnată HoriaRoman Patapevici şi în care ni se propune o problematizare a modernitătii. Volumul conține şapte conferințe despre situația de fapt a României culturale de azi şi abordeazã probleme care țin de filosofia culturii. România este vắzută lucid, sub toate aspectele ei culturale, iar autorul încearcă tocmai să contureze această identitate culturală. Patapievici dovedeşte şi aici spiritul polemic, urmând principiul dialogului cultural care îi provoacă de ani de zile pe actanții scenei culturale româneşti şi prin şi-a atras de multe ori oprobriul, pentru simplul fapt că a incomodat prin atitudinea directă, inteligentă şi în care Ideea este centrul existentei culturale. Senzația cititorului este aceea de a vedea la microscop atât situația de fapt a culturii româneşti, cât şi procesul prin care România a devenit o tară a culturii generale. Aflăm şi că un stat modern trebuie să întrunească patru condiții esențiale: cetățenie egală, instituţii reprezentative pentru toți cetățenii, economie de piaţă liberă, separarea puterilor în stat şi secularizarea tuturor valorilor sociale, iar România, chiar dacã nu a îndeplinit aceste condiţii odată cu Europa Occidentală, are totuşi şansa să îşi desăvârşească modernizarea azi. Problematica acestei cărți vine de fapt în întåmpinarea aderării României la Uniunea Europeanã din 2007, moment care însemna şi o integrare culturală a României în cultura variată a Europei. 
Eul, pe lângă problemele de filosofia şi istoria culturii abordate, oferă şi un episod de istorie personală, prin care Eul prezent devine conştient de propriul destin, prin încadrarea micro-istoriei în macro-istorie, a istoriei familiilor din partea mamei şi a tatălui care s-au întâlnit şi şi-au născut fiul în umbra/lumina ruperii Bucovinei de țara-mamã:

Dacă eu m-am putut naşte, este pentru cã pãrinții mei s-au întảlnit. Fireşte! Dar nu pot să uit nici o clipã cẫ întảlnirea lor a fost posibilã numai şi numai pentru că tinutul în care tatăl meu $\mathrm{s}$-a născut a fost rupt de la țara mea şi a fost alipit la URSS. Sunt un produs neintenționat al catastrofelor care au ruinat multe dintre tările acelei pấrți ale lumii și, de aceea, simt că am datoria să mărturisesc pentru viitor vina acelor timpuri atroce (Patapievici, 2004: 19).

Capitolul Despre rănile nevindecate devine o mărturie a istoriei, iar Eul devine purtătorul de mesaj al celor care, în acel timp al istoriei la care se face referire, nu au putut vorbi şi care se fac acum auziți în acea parte a lumii care ştie ,despre România doar eventual că existã” (Patapievici, 2004: 225) şi care consideră „că multinaţionalele sunt mai periculoase decât comunismul, că Uniunea Sovietică nu a exterminat oameni şi că ideile marxist-leniniste sunt de cel mai înalt respect" (Patapievici, 2004: 225), acest loc fiind Australia, Brisbane, unde autorul a ținut această conferință în 1997.

Acestea sunt ipostaze ale Eului care se mărturiseşte azi în România, Eul intelectual, cultivat, care se mărturiseşte pe Sine şi propria lume şi care se proiectează atât înăuntrul cât şi în afara Ființei, într-o atitudine de boierime a minţii, în care domneşte ideea, oferind astfel o panoramã a pulsului cultural, social şi politic al Româniilor de azi. Exercițiul de expunere practicat de fiecare dintre cei trei intelectuali este unul care creează un echilibru între lumea din afară şi cea dinăuntru, şi care, înainte de toate, dă măsura vieții intelectuale româneşti de azi.

\section{REFERINTTE BIBLIOGRAFICE}

Ciobanu V. (2002), „Jurnalul unui filosof 'apostat", Contrafort, 12/98, Decembrie, http://www. contrafort.md/2002/98/448.html, 10.03.2005.

Cristea D. (2004), Autorul şi Ficţiunile Eului, Bucureşti : Editura Cartea Româneascā.

Liiceanu G. (2001), Declaratie de iubire, Bucureşti : Editura Humanitas.

Liiceanu G. (2003), Uşa interzisă, Bucureşti : Editura Humanitas.

Parfit D. (2002), „Ceea ce credem că suntem”, Secolul 21, Alteritate, nr. 1-7, Revistă editatā de Uniunea Scriitorilor din România şi Fundaţia Secolul 21.

Patapievici H.-R. (2004), Discernấmântul modernizãrii, Bucureşti : Editura Humanitas.

Patapievíci H.-R. (1995), Zbor în bătaia sãgeții. Eseu asupra formăriii, Bucureşti : Editura Humanitas.

Pleşu A. (2005), Comédii la Portile Orientului, Bucureşti : Editura Humanitas.

Vasile S., „Fila de dicționar” în Familia, Revistã culturală fondatã de Iosif Vulcan în 1865, http://revistafamilia.uv.ro/2004/9-2004/fila_de_dictionar.htm, 10.03.2005.

Ovidiu Ş., „Trâiesc atîta vreme cît mã indignez”. Interviu cu Gabriel Liiceanu”, Observator cultural, no. $302,302,304$, http://observatorcultural.ro/, 10.03.2005. 